\title{
Types of Parvalbumin-Containing Retinotectal Ganglion Cells in Mouse
}

\author{
Chae-Woo Yi ${ }^{1}$, Song-Hee Yu ${ }^{1}$, Eun-Shil Lee ${ }^{1}$, Jee-Geon Lee ${ }^{1}$ and Chang-Jin Jeon ${ }^{1}$ \\ ${ }^{1}$ Department of Biology, College of Natural Sciences, and Brain Science and Engineering Institute, Kyungpook National University, \\ Daegu, 702-701, South Korea
}

Received December 16, 2011; accepted April 25, 2012; published online June 19, 2012

\begin{abstract}
The calcium-binding protein parvalbumin (PV) occurs in the retinal ganglion cells (RGCs) of various vertebrate species. In the present study, we aimed to identify the types of PVcontaining RGCs that project to the superior colliculus (SC) in the mouse. We injected retrograde tracer dextran into the mouse SC to label RGCs. PV-containing RGCs were first identified by immunocytochemistry and then neurons double-labeled with dextran and PV were iontophoretically injected with a lipophilic dye, Dil. Subsequently, confocal microscopy was used to characterize the morphologic classification of the PV-immunoreactive (IR) retinotectal ganglion cells on the basis of dendritic field size, branching pattern, and stratification within the inner plexiform layer. Among the 8 different types of PV-containing RGCs in the mouse retina, we found all 8 types of RGCs projecting to the SC. The RGCs were heterogeneous in morphology. The combined approach of using tracer injection and a single cell injection after immunocytochemistry on a particular protein will provide valuable data to further understand the functional features of the RGCs which constitute the retinotectal pathway.
\end{abstract}

Key words: parvalbumin, retinal ganglion cell, superior colliculus, cell type, cell injection

\section{Introduction}

Visual information undergoes a first step of processing in the retina, and retinal ganglion cells (RGCs) project to particular visual targets in the brain. Thus, with the advent of modern techniques, the morphological and functional properties of RGCs have been studied in variety of species. The 3 most common types of RGCs have been distinguished in the monkey retina: Large magnocellular (parasol), smaller parvocellular (midget) and small bistatified ganglion cells [11, 33]. Recently, however, at least 8 previously unknown RGCs that project to the lateral geniculate nucleus were identified by using an in vitro photostaining method [12] and at least 15 types of widefield RGCs were identified by microinjection with neurobiotin [48]. In the cat, 2 classes of morphologically distin-

Correspondence to: Prof. Chang-Jin Jeon, Neuroscience Lab., Department of Biology, College of Natural Sciences, Kyungpook National University, 1370 Sankyuk-dong, Daegu, 702-701 S. Korea. E-mail: cjjeon@knu.ac.kr guished RGCs (small beta and large alpha cells) have been shown to correspond to the physiologically defined $\mathrm{X}$ and $Y$ cells. Similarly, these retinas have a gamma-type ganglion cell corresponding to a $\mathrm{W}$ cell $[5,37,46]$. However, at least 9 types of RGCs were seen anatomically to be non-beta, non-alpha cells, by using intracellular staining $[17,30]$. Eleven different types of RGCs were distinguished in the rabbit retina, by using a combination of sophisticated anatomic techniques [32].

The mouse retina is a valuable model for vision research because the mouse is a mainstay of transgenic technology. Therefore, Sun et al. [39] have used DiI particle bombardment to describe 14 types of RGCs. Kong et al. [21] and Coombs et al. [9] have analyzed 11-14 RGCs clusters in the mouse retina using various methods to label cells. Badea and Nathans [2] have analyzed 12 RGC types in the mouse using a genetically directed reporter. Recently, Völgyi et al. [44] have morphologically analyzed 22 RGC subtypes based on soma-dendritic parameters in the mouse. Furthermore, our previous studies have shown the morphology of RGCs with the expression of parvalbumin (PV) 
[20] and calretinin [22] by using a newly developed singlecell injection method following immunocytochemistry.

Among the many calcium-binding proteins, at least 3 of the EF-hand calcium-binding proteins, calbindin D28K, calretinin and PV have been applied as good markers to distinguish subpopulations of neurons [3]. Calcium plays a crucial role in cell signal transduction, neurotransmitter secretion and muscle contraction. Calcium-binding proteins are thought to control and modulate these cellular mechanisms of calcium. Misregulation of calcium-binding proteins is closely related to many neurodegenerative diseases [15]. In particular, the expression of parvalbumin (PV) in the nervous system is restricted to the neurons, and mostly to a GABAergic subpopulation of neurons [8]. Recently, neural circuits with PV-immunoreactive (IR) neurons have been studied in the brain and gradually were shown to function in the neural circuity. Although the systematic study of RGC types with its expression of a particular protein has been previously accomplished for PV and calretinin in the mouse $[22,26]$, the types of RGCs that project to the superior colliculus (SC), and their expression of specific proteins, have not been studied.

In general, many RGCs project to the lateral geniculate nucleus in the thalamus and SC in the midbrain. The SC is the center of visual motor integration, and controls saccadic movement of eyes. A number of studies have been performed to correlate the distribution and various physiological types of RGCs with the SC [10, 27, 31, 43, 45].

In the present study, we have extended the systematic morphological analysis approach to the study of mouse RGCs with their expression of specific proteins. Our study aimed to identify morphological types PV-containing RGCs with their retinotectal pathways by using advanced approaches. The advanced approach we chose involved triple labeling techniques: retrograde tracer injection and single-cell injection of lipophilic dye, following immunocytochemistry.
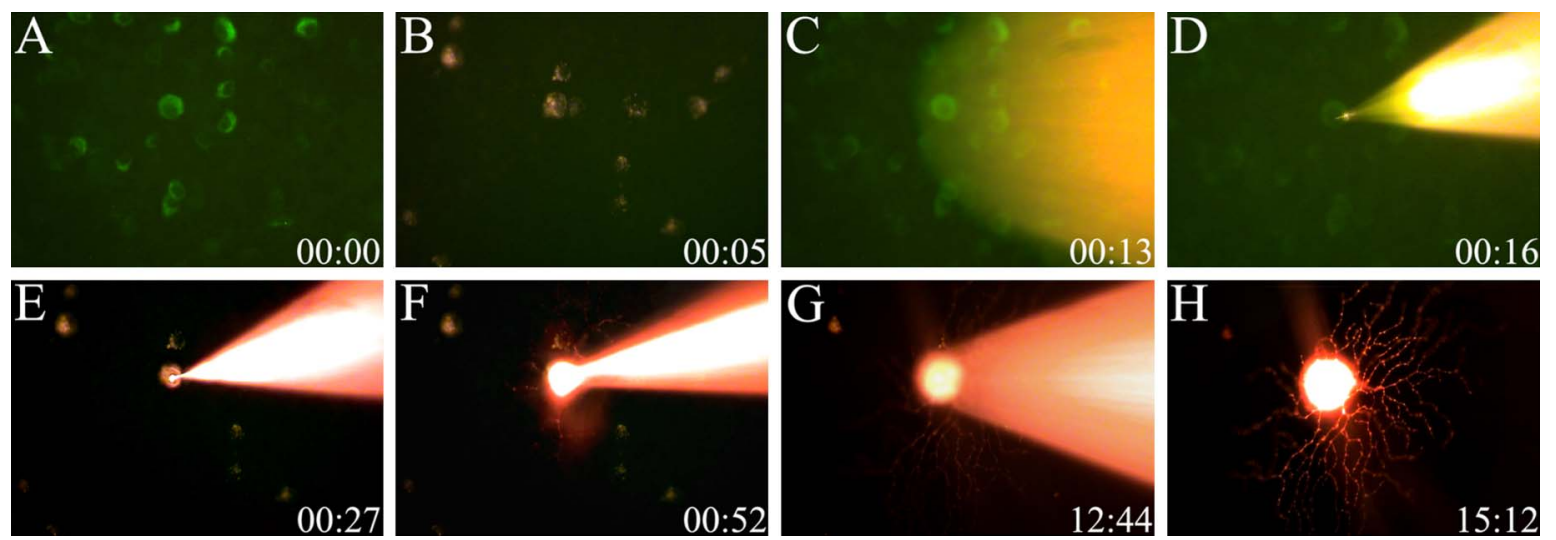

Fig. 1. Single cell injection into parvalbumin (PV) and dextran co-localized neurons on the whole-mounted retina. (A) PV-containing neurons were labeled with a monoclonal antibody against PV. (B) Retrogradely injected tracer dextran-labeled neurons in the retina. (C, D) A DiI-filled micropipette targeted double-labeled neurons. (E-H) A DiI-Filled neuron revealed the distinctive morphological pattern. Note the axon of targeted cell in (E). FITC-labeled PV-containing neurons (A-D) were viewed with a water-immersion lens, using a $100 \mathrm{~W}$ mercury source and Zeiss filter set 09. The DiI-filled cells $(\mathbf{E}-\mathbf{H})$ were viewed using another filter set 20. 

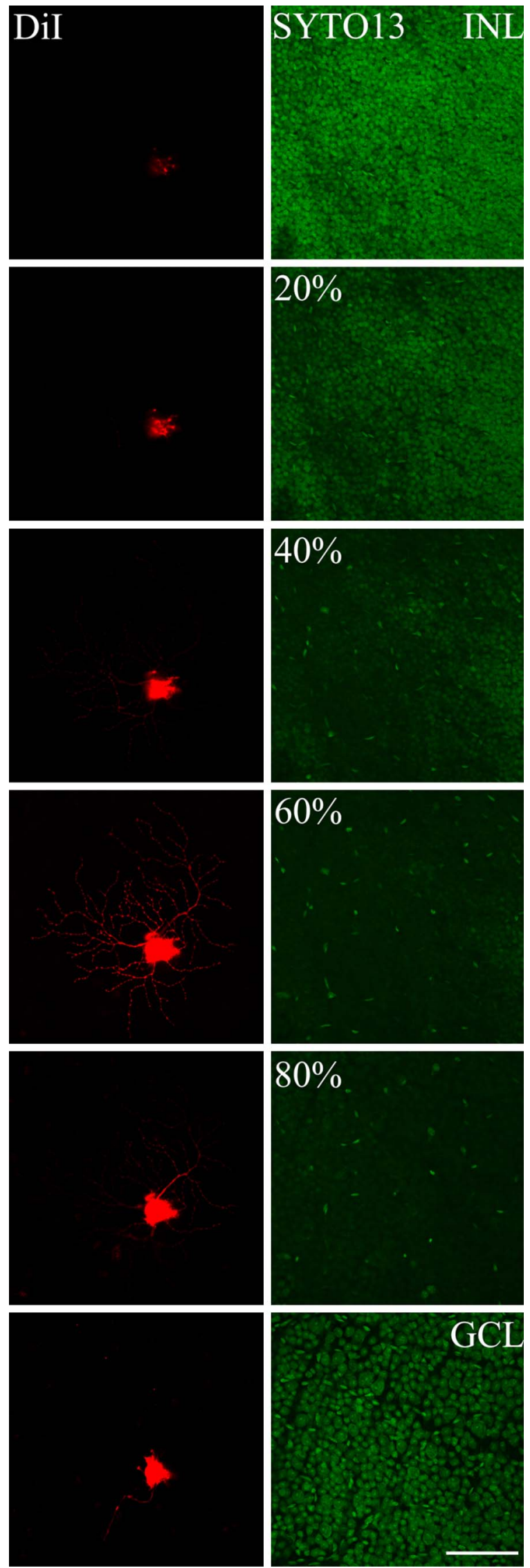

solution for 2-3 hr. The brain was removed from the skull, stored for 2-3 hr in the same fixation solution, and left overnight in $0.1 \mathrm{M} \mathrm{PB}(\mathrm{pH} 7.4$ ) containing $8 \%$ sucrose and $0.002 \%$ calcium chloride. The SC was removed, mounted onto a chuck, and cut into $50 \mu \mathrm{m}$ thick sections with a Vibratome. The tissues were coverslipped with Vectashield mounting medium (Vector Laboratories, Burlingame, CA, USA).

\section{Immunocytochemistry}

After enucleation, the retinas were carefully isolated from the eye cup in $0.1 \mathrm{M} \mathrm{PB}(\mathrm{pH} 7.4)$ and mounted onto a black, nonfluorescent filter membrane $(0.45 \mathrm{~mm}$, Black, HABP $47 \mathrm{~mm}$; Millipore, Bedford, MA, USA) with the ganglion cell layer upper. The filter membrane and the attached retina were fixed for $30 \mathrm{~min}$ in a dish containing $4 \%$ paraformaldehyde in $0.1 \mathrm{M} \mathrm{PB}(\mathrm{pH} 7.4)$. After 3 rinses in $0.1 \mathrm{M} \mathrm{PB}$, we used conventional immunocytochemical techniques that we previously described in detail [18]. Briefly, the tissues were labeled with monoclonal antibodies against PV (1:100-200, Sigma-Aldrich, Temecula, CA, USA), in $0.1 \mathrm{M} \mathrm{PB}$ for $2 \mathrm{hr}$. The secondary antibody used was FITC-conjugated horse anti-mouse IgG (1:50; Vector Laboratories) in $0.1 \mathrm{M} \mathrm{PB}$ for 1 to $2 \mathrm{hr}$.

\section{Cell injection}

The fundamental procedure for single-cell injection following immunocytochemistry on whole mount retina has been previously described in detail [19, 20, 22] and therefore will be presented in a brief outlined. The FITCand dextran-labeled neurons were viewed with a microscope equipped with a Zeiss 40X Plan Achroplan (NA 0.80) water-immersion lens and Zeiss filter set 09 (excitation, 450-490 nm; emission, $515 \mathrm{~nm}$ ). The co-localized cell was filled iontophoretically by passing a positive current of 5-20 nA and 0.2-0.5 mV with 1\% lipophilic dye, DiI (1\% DiI in ethanol; Molecular Probes, Eugene, OR, USA) [19]. The optimal filling time was 15-30 min (Fig. 1). When the selected cell was filled, the grid reticle was moved laterally and another cell was injected into the near center of the grid. After several cells in the retina were filled, the tissue was

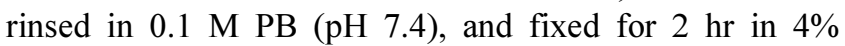
paraformaldehyde. To counterstain the tissue, the retina was immersed for $1 \mathrm{hr}$ in a nucleic acid dye SYTO13 (10-20 $\mathrm{nm}$; Molecular Probes). The tissue was coverslipped with Vectashield mounting medium (Vector Laboratories).

\section{Data analysis}

The cells were imaged using a confocal scanning module (LSM 700, Carl Zeiss Meditec Incorporation, Jena, Germany) mounted on a fluorescence microscope (Axio Observer.Z1, Carl Zeiss) equipped with a C-Aporchment

Fig. 2. Determining the level of dendritic stratification of PV-filled retinal ganglion cells (RGCs). Through-focus series of DiI-injected cell (left column), and SYTO 13 (right column) were matched. INL, inner nuclear layer; GCL, ganglion cell layer. Bar=50 $\mu \mathrm{m}$. 
40×/1.20w Korr M27 for small cells and an Aporchment $20 \times / 1.20$ w Korr M27 for large cells. Two sets of images were collected of each injected cell. A through-focus of the DiI-filled cells was imaged using an emission filter (580DF32; Chroma Technology Corp., Rockingham, VT, USA). Subsequently, a through-focus of the nucleic acidstained (SYTO13; Molecular Probes) nuclei was collected using an emission filter (515DF30), to measure the thickness of the inner plexiform layer (IPL) and to determine the level of stratification of the DiI-filled cells. The ganglion cell layer (GCL)/IPL boundary was defined as $100 \%$ and the IPL/inner nuclear layer (INL) boundary was defined as $0 \%$. The $\mathrm{z}$-coordinate of each dendritic branch was measured from the distance between GCL/IPL and the IPL/INL boundaries (Fig. 2). The dendritic field area and diameter were computed with a ZEN 2009 program (Carl Zeiss Microimaging GmbH 2006-2009) by connecting the distal most tips of the dendrites [33]. Images were adjusted in terms of brightness and contrast (Photoshop CS; Adobe Systems, Mountain View, CA, USA).

\section{Results}

\section{Retrograde tracer injection into $\mathrm{SC}$}

In the present study, 25 mice were used to precisely detect RGCs which projected to the SC. In most cases, retrograde tracer (dextran, tetramethylrhodamine, 3000 MW) injections were applied to visual layers of the SC (Fig. 3A). However, some tracers diffused into other layers of the SC where retinal fibers have been known to terminate relatively sparsely. Forty-eight hours after these injections, retrogradely labeled cells were obviously identified as retinotectal RGCs in mouse retinas. Following experimental procedures, retrogradely labeled RGCs and PV-containing RGCs in isolated retinas were confirmed by a microscope equipped with a water-immersion lens (Fig. 3B and 3C). In present study, we also found many PV-IR RGCs were not labeled by tracer in the area where tracer filled many PV-IR RGCs. Therefore, Fig. 3D (arrows) shows doublelabeled cells of the retinotectal pathway. These cells were applied to single-cell injection of lipophilic dye.

\section{Topography of RGCs that project to $S C$}

The location and extent of the dextran labeling in the retina differed in most cases. These are caused by the differences in location and extent of the injections in the SC. Dextran-labeled RGCs located at intermediate retinal positions projected to corresponding intermediate positions along the cranial-caudal axis of the SC. Thus, RGCs in the nasal retina projected to targets at the far caudal portion of the $\mathrm{SC}$, and RGCs in the temporal retina project to targets at the far rostral end of the SC [4, 13, 23]. After injecting dextran into the rostral $\mathrm{SC}$ on the right side, the retinal portions of retrogradely labeled cells were seen to be located in the temporal area (Fig. 4A). In all cases, the labeled cells were irregularly spaced within the retinal region of labeled cells, and a wide range of ganglion cells projected to the SC (Fig. 4). Our finding in mouse retina was similar to the results of studies in rodent species [27, 31, 43].

\section{Types of $P V$-containing RGCs that project to $S C$}

Our previous study has revealed that $28.98 \%(13,003 /$ 44,587) of RGCs in the mouse express PV [20]. In the present study, 108 RGCs from 25 retinas were analyzed by a laser scanning confocal microscope. Ganglion cells were identified by the presence of an axon after DiI injection. For simplicity and to avoid controversy regarding ganglion cell types or clusters within the mouse and between species [9, $21,32,39]$, we did not rely on pre-existing names. Instead, PV-containing RGCs with their retinotectal pathway were classified by dendritic field size, branching pattern, and stratification within IPL. We also used a simple name, as in the previous study, PV cell types with their retinotectal pathways 1 through 8 (PV1-8; Table 1). However, each cell type corresponds to the recent classification of Sun et al. [39]. A description of cells follows the order of their dendritic field diameter.

PV1 cells possessed a small dendritic field (Fig. 5), with dendrites exhibiting abrupt bends and turns along their course. The field diameter of the cells was $166 \pm 33 \mu \mathrm{m}$. The dendritic arbors branched in the outer part of the IPL (33.68 $\pm 2.33 \%$, Fig. 8). As previously reported [20], the
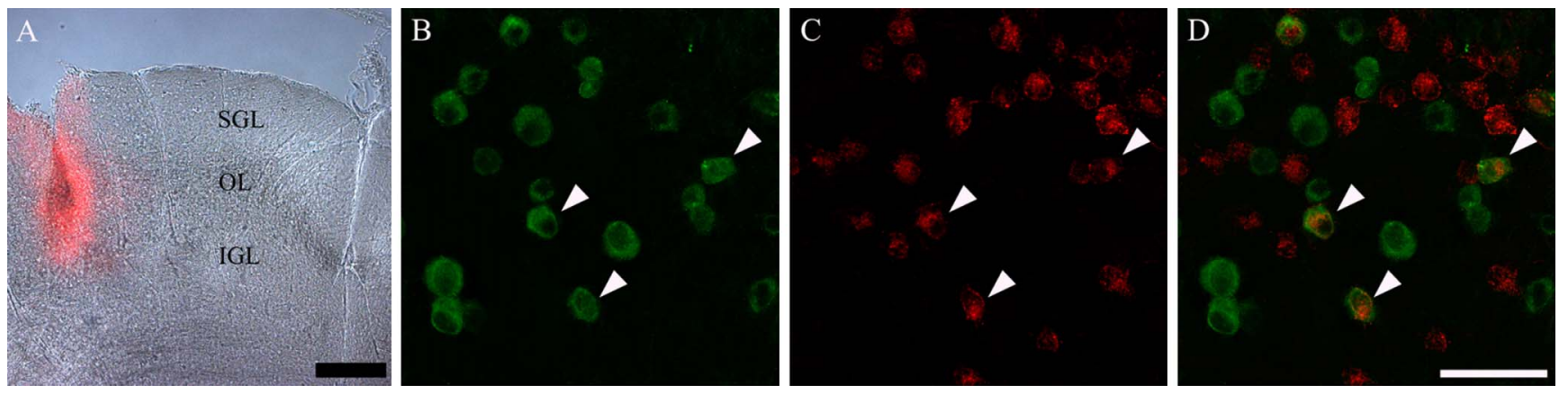

Fig. 3. Retrograde fluorescent tracer dextran injection into the mouse superior colliculus (SC). (A) Injection site of the SC. (B) PVimmunoreactive (IR) cells in the ganglion cell layer of the retina. (C) Dextran containing cells in the same focus as (B). (D) Merged image of (B) and (C). Some cells (arrowheads) are clearly co-localized by anti-parvalbumin antibody and dextran in the mouse retina. SGL, superficial gray layer; OL, optic layer; IGL, intermediate gray layer. Bars=100 $\mu \mathrm{m}(\mathbf{A}), 50 \mu \mathrm{m}(\mathbf{D})$. 

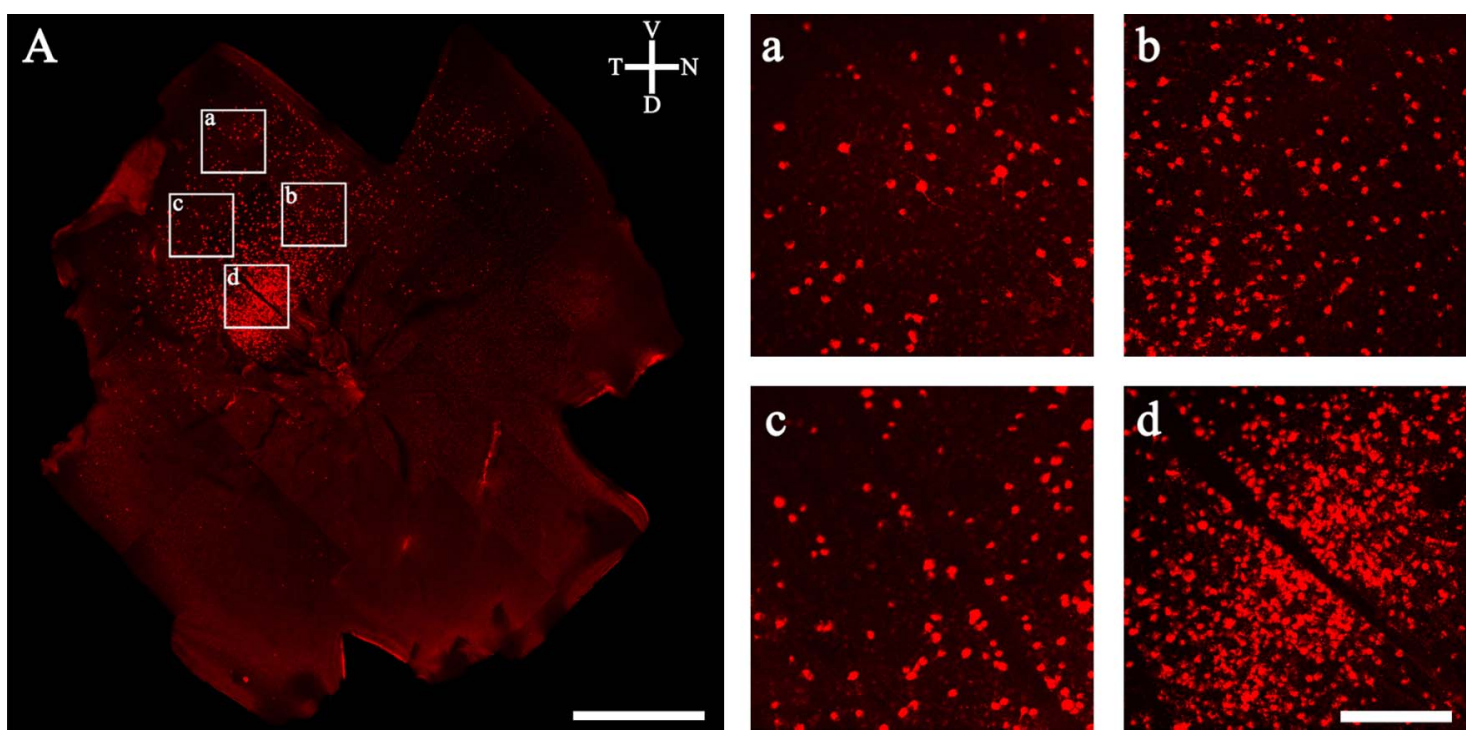

Fig. 4. (A) Distribution of retrogradely labeled ganglion cells after injections into the SC. High magnification of dextran labeled cells in the whole mount mouse retina: (a) peripheral region, (b)-(c) mid central regions and (d) central region. Bars=1 mm (A), $200 \mu \mathrm{m}(\mathbf{a}-\mathbf{d})$.

dendritic arbors contained many short branches and were often asymmetric. It was obvious that PV1 cells belong to type B4 (Table 1).

PV2 cells possessed a sparse dendritic field that was curvy and recursive (Fig. 5). PV2 cells came in ON and OFF varieties. The field diameter of the ON variety was $227 \pm 35 \mu \mathrm{m}$, whereas the dendritic field of the OFF variety was $191 \pm 33 \mu \mathrm{m}$. These cells were stratified in the inner IPL $(64.74 \pm 5.25 \%)$ or the outer IPL $(30.35 \pm 4.95 \%)$. As previously reported [20], the dendritic branches were moderately wavy and were mostly longer than those of PV1. PV2 cells appeared to belong to type B3 [39].

PV3 cells possessed medium and medium-dense dendritic fields (Fig. 6). These cells were bistratified in the IPL with at a depth of $57.21 \pm 8.29 \%$ and $29.01 \pm 8.54 \%$ with a dendritic field diameter of $193 \pm 37 \mu \mathrm{m}$. They comprised $21.3 \%$ of our sample. PV3 cells had thin, recursive, loop-forming dendrites. They were very similar to the ONOFF direction selective cells that have been extensively described in the rabbit [49] and mouse retinas [47]. PV3 cells appeared to belong to type D2 [39].

PV4 cells possessed medium-to-large and mediumdense dendritic fields (Fig. 6). The field diameter of the cells was $226 \pm 18 \mu \mathrm{m}$, and they stratifying in the outer IPL (34.57 $\pm 6.47 \%)$. They had 3-5 primary dendrites that tapered from the soma to the periphery. The dendritic arbors covered the dendritic field evenly and were often asymmetric. PV4 cells corresponded to type C5 [39].

Table 1. Quantitative data of parvalbumin-containing mouse $R G C$ in this study and their homologues from previous data

\begin{tabular}{|c|c|c|c|c|c|c|c|c|}
\hline \multirow[b]{2}{*}{ Cell Type } & \multirow{2}{*}{$\begin{array}{c}\text { Dendritic Field } \\
\text { Position } \\
\text { (\% of IPL Depth; } \\
\text { Mean } \pm \text { SD) }\end{array}$} & \multirow[b]{2}{*}{$\begin{array}{l}\text { Number in } \\
\text { Sample }\end{array}$} & \multirow[b]{2}{*}{$\begin{array}{c}\% \text { of Total } \\
\text { Ganglion } \\
\text { Cell Filled }\end{array}$} & \multirow[b]{2}{*}{$\begin{array}{c}\text { Dendritic Field } \\
\text { Diameter } \\
(\mu \mathrm{m} ; \text { Mean } \pm \mathrm{SD})\end{array}$} & \multirow[b]{2}{*}{$\begin{array}{l}\text { Dendritic } \\
\text { Field Area } \\
\qquad\left(\mu \mathrm{m}^{2}\right)\end{array}$} & \multicolumn{3}{|r|}{ Sun et al. [39] } \\
\hline & & & & & & Type & $\begin{array}{c}\text { \% of } \\
\text { Total } \\
\text { RGCs }\end{array}$ & $\begin{array}{c}\text { Classification Scheme } \\
\text { (Dendritic Field Size/density) }\end{array}$ \\
\hline PV 1 & $33.68 \pm 2.33$ & 5 & 4.6 & $166 \pm 33$ & 19707 & B4 & 5.7 & Small/dense \\
\hline \multirow[t]{2}{*}{ PV $2 *$} & $64.74 \pm 5.25$ & 9 & 19.4 & $227 \pm 35$ & 37635 & B3 & 10.6 & Small to medium/sparse \\
\hline & $30.35 \pm 4.95$ & 12 & & $191 \pm 33$ & 25306 & & & \\
\hline \multirow[t]{2}{*}{$\mathrm{PV} 3^{+}$} & $57.21 \pm 8.29$ & 23 & 21.3 & $193 \pm 37$ & 27456 & D2 & 15.5 & Medium/medium \\
\hline & $29.01 \pm 8.54$ & & & & & & & \\
\hline PV 4 & $34.57 \pm 6.47$ & 12 & 11.1 & $226 \pm 18$ & 38838 & $\mathrm{C} 5$ & 11.2 & Medium/medium \\
\hline PV 5 & $28.93 \pm 4.57$ & 15 & 13.8 & $219 \pm 46$ & 35198 & $\mathrm{C} 4$ & 5.9 & Medium/dense \\
\hline \multirow[t]{2}{*}{ PV 6* } & $65.11 \pm 6.10$ & 7 & 11.1 & $273 \pm 30$ & 51381 & $\mathrm{C} 2$ & 10.2 & Medium to large/sparse \\
\hline & $35.07 \pm 4.33$ & 5 & & $257 \pm 22$ & 47762 & & & \\
\hline PV 7 & $57.02 \pm 1.43$ & 5 & 4.6 & $248 \pm 35$ & 48186 & $\mathrm{C} 1$ & 3.2 & Medium to large/medium \\
\hline PV 8 & $65.5 \pm 4.62$ & 15 & 13.8 & $297 \pm 52$ & 67007 & A1 & 4.5 & Large/sparse \\
\hline Total & & 108 & 100 & & & & & \\
\hline
\end{tabular}

* Monostratified cell type with ON and OFF population.

${ }^{\dagger}$ Bistratified cell type. 

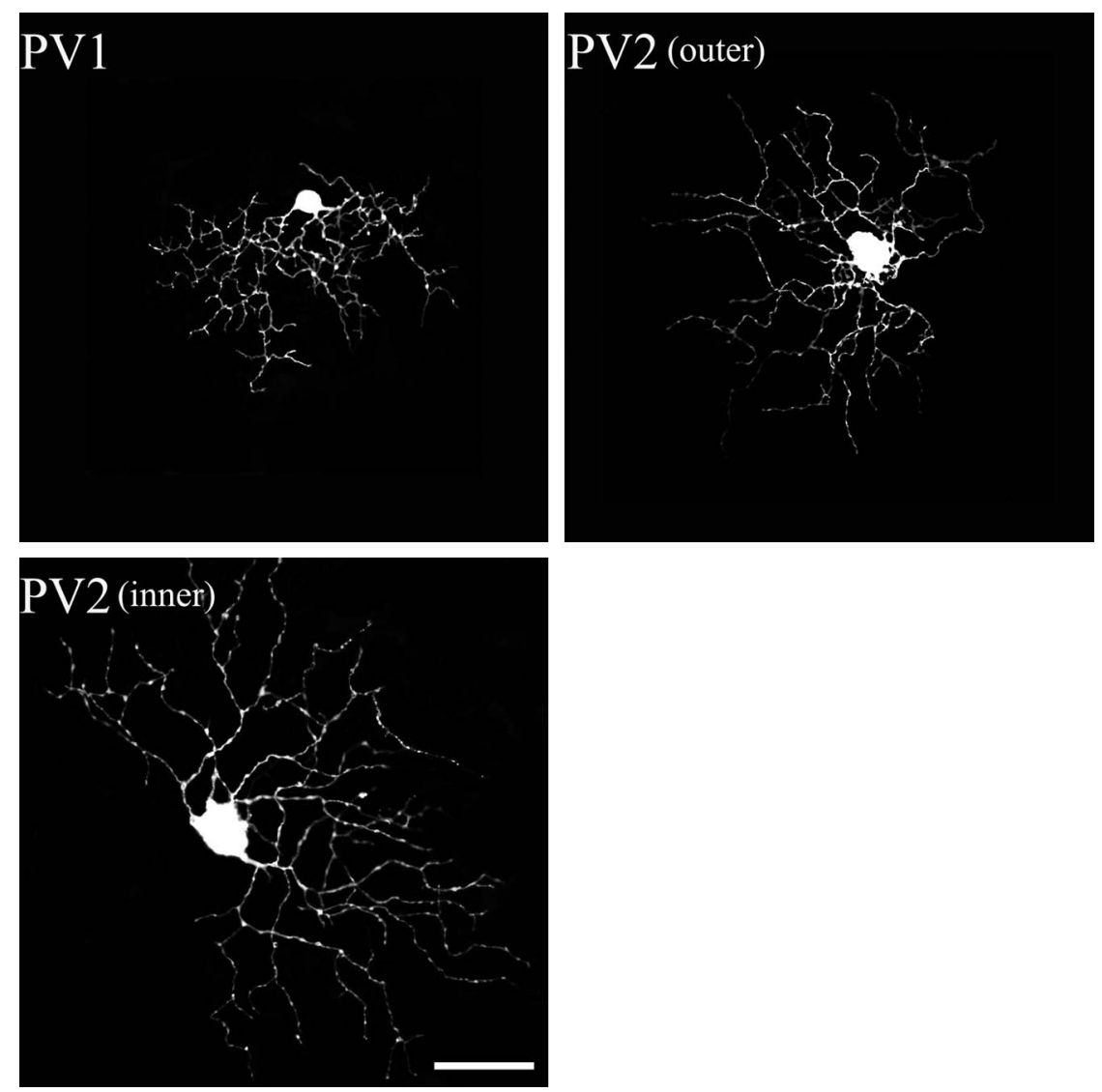

Fig. 5. PV-IR RGCs from the mouse SC. The PV1 and PV2 types of PV-containing retinotectal ganglion cells were identified in the present study. Each type corresponded to Sun et al.'s classification [39]. Bar $=50 \mu \mathrm{m}$.
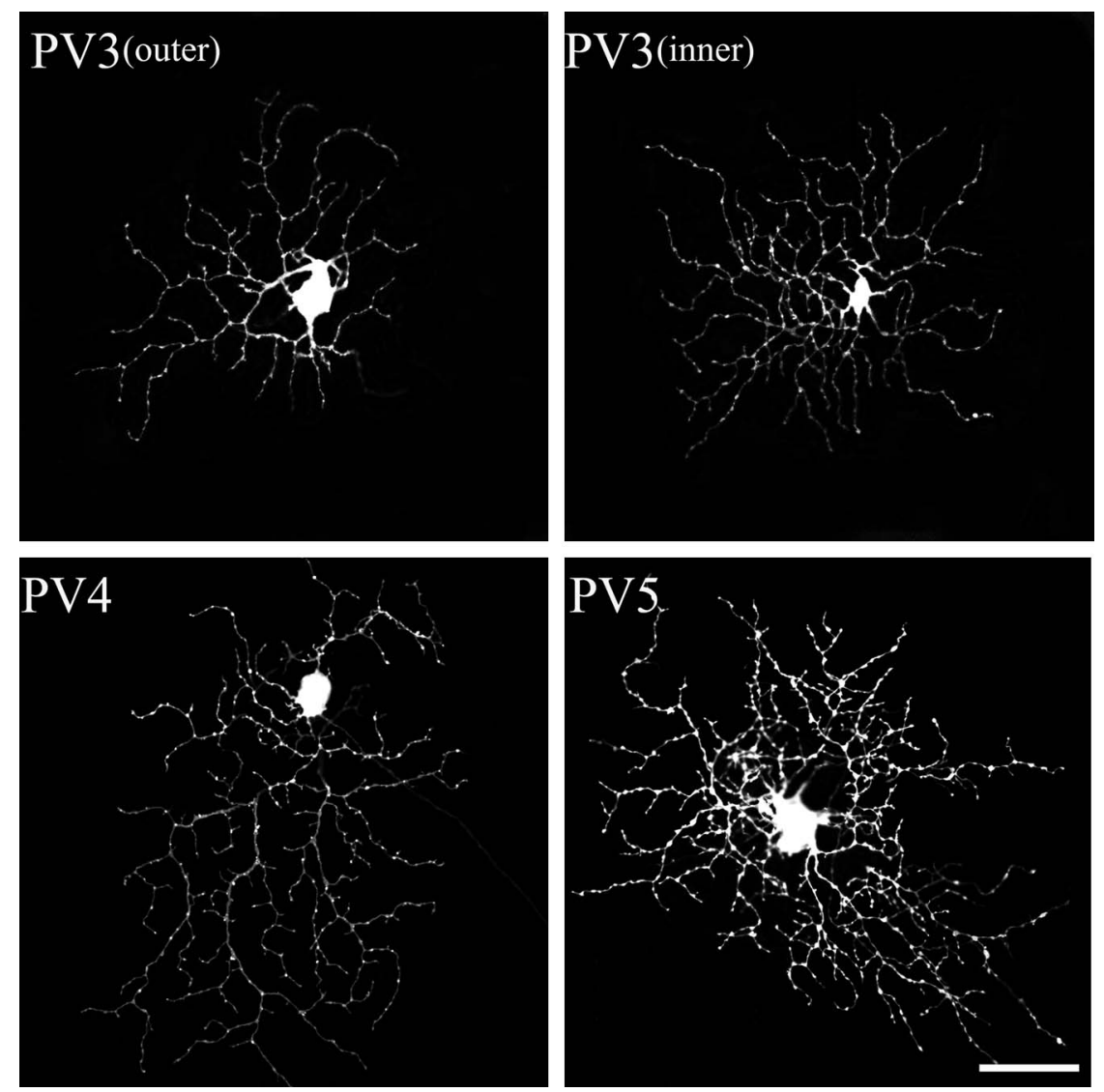

Fig. 6. PV-IR RGCs from the mouse SC. The PV3 to 5 types of PV-containing retinotectal ganglion cells were identified in the present study. Each type corresponded to Sun et al.'s classification [39]. Bar $=50 \mu \mathrm{m}$. 

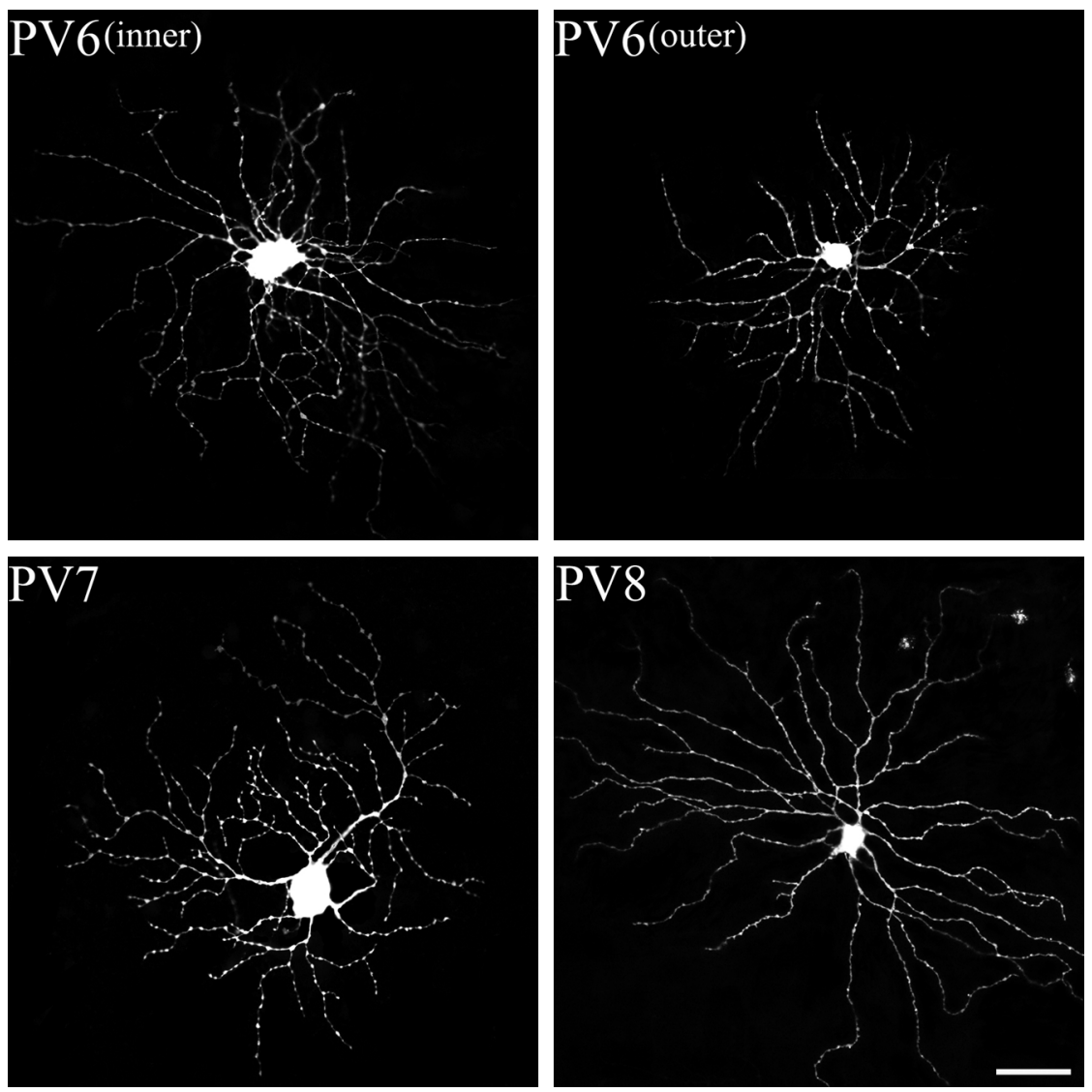

Fig. 7. PV-IR RGCs from the mouse SC. The PV6 to 8 types of PV-containing retinotectal ganglion cells were identified in the present study. Each type corresponded to Sun et al.'s classification [39]. Bar $=50 \mu \mathrm{m}$.

PV5 possessed medium-to large, relatively dense dendritic fields (Fig. 6). The field diameter of the cells was $219 \pm 46 \mu \mathrm{m}$, and they stratified in the outer IPL $(28.93 \pm 4.57 \%)$. As previously reported [20], these cells had 3-6 primary dendrites that were generally smooth, with compact and densely branched dendritic fields. The dendritic arbors overlapped in many fields of the cells. PV5 cells appeared to belong to type C4 [39].

PV6 possessed large and medium-sparse dendritic fields (Fig. 7). PV6 came in ON and OFF varieties. The field diameter of the $\mathrm{ON}$ variety was $273 \pm 30 \mu \mathrm{m}$, whereas the dendritic field of the OFF variety was $257 \pm 22 \mu \mathrm{m}$. These cells were stratified in the inner IPL $(65.11 \pm 6.10 \%)$ or outer IPL (35.07 $\pm 4.33 \%)$. As previously reported [20], these cells were characterized by irregular-looking dendritic arbors, which lacked an orderly, radiating pattern. PV6 cells corresponded to type C2 [39].

PV7 cells possessed large and medium-dense dendritic arbors (Fig. 7). The dendritic field diameter of the cells was $248 \pm 35 \mu \mathrm{m}$. The dendritic arbor branched in the inner part of the IPL $(57.02 \pm 1.43 \%)$. These cells had 3-5 primary dendrites, and the dendritic processes rarely crossed one another. They were very similar to the ON-direction selective cells that have been extensively described in mouse retinas [40]. PV7 cells corresponded to type C1 [39].

PV8 cells possessed large, sparse dendritic arbors (Fig. 7). They stratified at $65.5 \pm 4.62 \%$ of the IPL, with a dendritic field diameter of $297 \pm 52 \mu \mathrm{m}$. These cells had 3-6 primary dendrites, from which the process extended radially from a soma, emitting several long branches along the way. PV8 cells were similar to the ON variety of alpha cells of most mammalian retinas [26], and appeared to belong to type A1 [39].

\section{Discussion}

In the present study, we identified PV-IR retinotectal cells in the mouse retina by using a triple-labeling technique. The newly advanced method is especially useful for matching a neuron's morphology with its protein content and neural pathway.

The recent evidence strongly indicates that the family members of each major RGC type in the retina have all been identified. It is clear that mammalian retinas contain 10-15 different RGC types [28]. Sun et al. [39] classified at least 14 RGC types in the mouse. Among these 14 types, our previous study [20] has shown that at least 8 different types expressed PV. These types were A1, B3, B4, C1, C2, C4, C5 and D2 [39]. The present study indicated that all these 8 types of PV-IR RGCs project to the mouse SC. These cells have a small to large dendritic field size. We also have shown that RGCs retrogradely labeled with dextran were found in an orderly retinotopic fashion relative to the SC $[4,13,23]$. Studies in PV-IR RGCs of the 

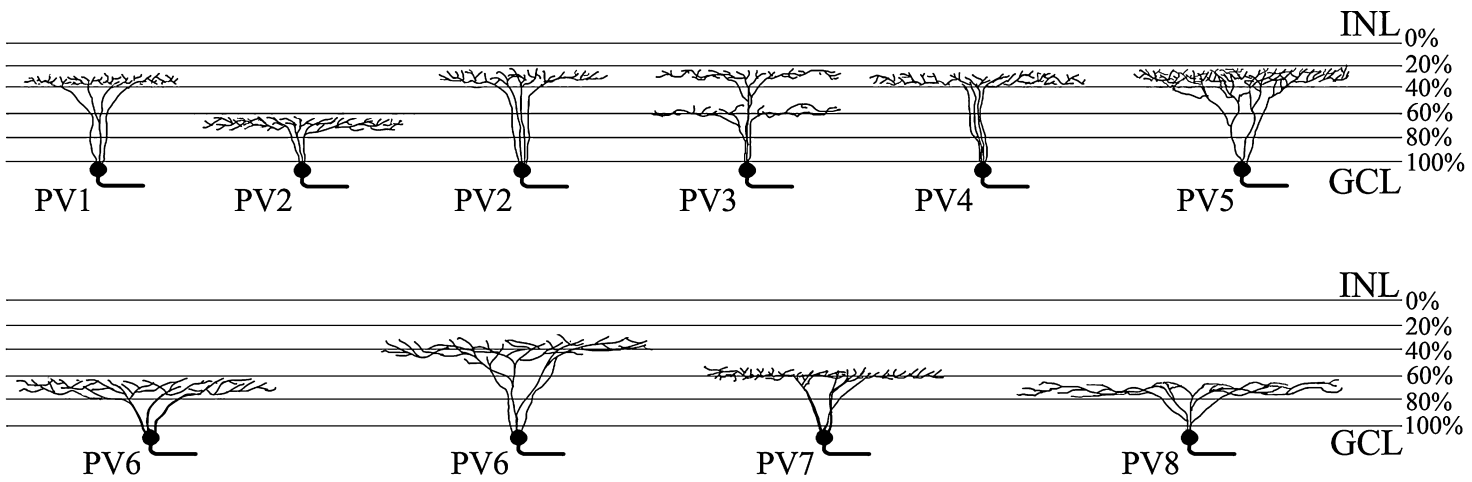

Fig. 8. The branching and levels of stratification of the 8 types of PV-IR mouse RGCs identified in our study. Bar=50 $\mu \mathrm{m}$.

various mammalian retinas suggest that PV-IR RGCs, if not all RGCs, most likely belong to a different chemical subpopulation for each type [7, 36].

A series of conceptual and experimental advances have made it possible to identify the neural circuits of retinotectal neurons and the connection of RGCs in the retina to their terminations in the SC of midbrain $[1,4,10$, $13,23,27,31]$. In general, retinotectal RGCs as nonstandard cells have direction selectivity, local edge detector and suppressed-by-contrast receptive field (W type and Y type). They do not include standard cells underlying high resolution vision (X type). Non-retinotectal RGCs have standard concentric receptive fields $[6,29,41,42]$. Waleszczyk et al. [45] has presented a simplified schema of the cat visual system including the retinotectal pathway. All types, except for beta (X)-type ganglion cells, project to the SC. Thus, W type RGCs project to the most superficial cellular layer of the SC, the stratum zonale and the stratum griseum superficiale. Y type RGCs project to the lower portion of the stratum griseum superficial, and the upper portion of the stratum griseum intermediale $[4,17$, 24, 38]. Moreover, distribution of retinotectal RGCs was also revealed in the rabbit [43], rat [1] and ground squirrel $[27,31]$ by using retrograde staining. Especially, the ground squirrel RGCs were indentified in 4 types of retinotectal neurons, including the beta-type ganglion cell (X type). They have a variety of morphological types of RGCs projected to the SC. The present results of retrograde staining showed a variety of morphological types of RGCs in the mouse retina. Although the physiological functions of mouse RGCs types are still not fully understood, our present study provides evidence that PV-IR retinotectal RGCs in the mouse may possibly have W type and Y type RGCs. Sun et al. [39] assumed that A1 (PV8) type RGCs are equivalent to the alpha cell type (Y type). Our small PV-IR retinotectal RGCs (PV1 and PV2) could possibly belong to the $\mathrm{W}$ type RGCs, but confirmation requires further electrophysiological and ethological studies. However, PV-IR retinotectal RGCs do not have B2 type RGCs, which were assumed morphologically to be the beta cell type (X type). Thus, our results for PV-IR RGCs correspond with the previous results in most animals.

$\mathrm{PV}$ is thought to play a major role in buffering the intercellular calcium levels and a neuroprotective role from calcium overload. Moreover, PV-IR neurons in the brain can possibly modulate the pathway of principal neurons by controlling excitation and inhibition [14, 35]. It may be possible that the PV-IR RGCs especially contribute to neuroprotection and modulation of neural pathway activity. Our results indicated that retinotectal PV-IR RGCs were monostratified to bistratified, possessed a small-to-large dendritic field size, and had sparse-to-dense dendritic arbors. It is conceivable that PV is expressed in different types of RGCs to differentiate their special functions in specific cell types.

Specifically, it is conceivable that PV may be involved in low spatial resolution pattern vision and controlling the reflex direction of the gaze $(\mathrm{W})$ as well as nonlinear spatial summation within the receptive field (Y) [34, 41]. These results may assume that $\mathrm{PV}$ in small PV-IR retinotectal RGCs (PV1 and PV2) may contribute to interactions involved in local edge detection, and the PV in large PVIR retinotectal RGCs (A1) may contribute to interactions of suppression by contrast. Similarly, Y type RGCs have a large dendritic field and they also transmit signals of nonlinear spatial component within a receptive field to the SC in the cat [4] and primate [10]. Crook et al. [10] has shown that $\mathrm{Y}$ type RGCs (M) have collicular projections and have linear and nonlinear components of the receptive field. These cells conceivably corresponded to type PV8 in our results. However, the precise function of PV in each cell type needs more detailed studies and remains far from obvious.

Retinotectal RGCs also have a directionally selective response. Especially, On-direction selective ganglion cells and On-Off direction selective ganglion cells project to the lateral geniculate nucleus as well as the SC $[25,50]$. On direction selective RGCs and On-Off direction selective RGCs corresponded to type PV7 and PV3, respectively in our result. Although the function of $\mathrm{PV}$ in direction selective cells remains far from obvious, the presence of PV in these cells may suggest that PV play a certain role in 
modulating signals of direction selectivity. These assumptions also require further study.

In conclusion, the combined newly approach of cell morphology and the selective expression of PV within the neural pathway will provide useful data for further correlation of specific neural circuits of RGCs, and also provide a powerful strategy for matching a neuron's morphology with its expression of a specific protein. In the present study, our results have indicated that PV-IR retinotectal RGCs have all 8 types PV-IR RGCs that were heterogenous in morphology. PV-IR retinotectal RGCs may have functions similar to those of non standard RGCs, which interact with direction selectivity, local edge detection and suppressed-by-contrast. It is possible that PV-IR neurons have particular functional properties for modulating signals of the neural pathway for a specific niche adaptation. The combined method of triple labeling technique will lead to a better insight of the specific neural circuitry of RGCs.

\section{Acknowledgments}

We thank Language Edit for proofreading the paper. This work was supported by the Korea Research Foundation Grant funded by the Korea government, KRF-2008313-E00367.

\section{References}

1. Ahmed, A. K., Dong, K., Hanna, G. F. and Yamadori, T. (1998) Retrograde double-labeling study of retinal ganglion cells from the ipsilateral vLGN and SC in the albino rat. Neurosci. lett. 244; 47-51

2. Badea, T. C. and Nathans, J. (2004) Quantitative analysis of neuronal morphologies in the mouse retina visualized by using a genetically directed reporter. J. Comp. Neurol. 480; 331-351.

3. Baimbridge, K. G., Celio, M. R. and Rogers, J. H. (1992) Calcium-binding proteins in the nervous system. Trends Neurosci. 15; 303-308.

4. Berson, D. M. (1988) Retinal and cortical inputs to cat superior colliculus: composition, convergence and laminar specificity. Prog. Bain Res. 75; 17-26.

5. Boycott, B. B. and Wässle, H. (1974) The morphological types of ganglion cells of the domestic cat's retina. J. Physiol. 240; $397-419$

6. Casagrande, V. A. (1994) A third parallel visual pathway to primate area V1. Trends Neurosci. 17; 305-310.

7. Casini, G., Rickman, D. W., Trasarti, L. and Brecha, N. C. (1998) Postnatal development of parvalbumin immunoreactive amacrine cells in the rabbit retina. Brain Res. Dev. Brain Res. 111; 107117.

8. Celio, M. R. (1986) Parvalbumine in most $\gamma$-aminobutyric acidcontaining neurons of the rat cerebral cortex. Science 231; 995997.

9. Coombs, J. L., Van Der List, D., Wang, G. Y. and Chalupa, L. M. (2006) Morphological properties of mouse retinal ganglion cells. Neuroscience 140; 123-136

10. Crook, J. D., Peterson, B. B., Packer, O. S., Robinson, F. R., Troy, J. B. and Dacey, D. M. (2008) Y-cell receptive field and collicular projection of parasol ganglion cells in Macaque monkey retina. J. Neurosci. 28; 11277-11291

11. Dacey, D. M. (1994) Physiology, morphology and spatial densities of identified ganglion cell types in primate retina. Ciba
Found. Symp. 184; 12-28

12. Dacey, D. M., Peterson, B. B., Robinson, F. R. and Gamlin, P. D. (2003) Fireworks in the primate retina: in vitro photodynamics reveals diverse LGN-projecting ganglion cell types. Neuron 37; $15-27$.

13. Debski, E. A. and Cline, H. T. (2002) Activity-dependent mapping in the retinotectal projection. Curr. Opin. Neurobiol. 12; 9399.

14. Freund, T. F. (2003) Interneuron Diversity series: Rhythm and mood in perisomatic inhibition. Trends Neurosci. 26; 489-495.

15. Heizmann, C. W. (1995) Calcium Regulation by Calcium-binding Proteins in Neurodegenerative Disorder (Neurosicence Intelligence Unit), Springer-Verlag, New York.

16. Hof, P. R. (2000) Comparative Cytoarchitectonic Atlas of the C57BL/6 and 129/Sv Mouse Brains, Elsevier Science, Amsterdam.

17. Isayama, T., Berson, D. M. and Pu, M. (2000) Theta ganglion cell type of cat retina. J. Comp. Neurol. 417; 32-48.

18. Jeon, C. J., Strettoi, E. and Masland, R. H. (1998) The major cell populations of the mouse retina. J. Neurosci. 18; 8936-8946.

19. Kao, Y. H. and Sterling, P. (2003) Matching neural morphology to molecular expression: Single cell injection following immunostaining. J. Neurocytol. 32; 245-251.

20. Kim, T. J. and Joen, C. J. (2006) Morphological classification of parvalbumin-containing retinal ganglion cells in mouse: singlecell injection after immunocytochemistry. Invest. Ophthalmol. Vis. Sci. 47; 2757-2764.

21. Kong, J. H., Fish, D. R., Rockhill, R. L. and Masland, R. H. (2005) Diversity of ganglion cells in the mouse retina: unsupervised morphological classification and its limits. J. Comp. Neurol. 489; 293-310.

22. Lee, E. S., Lee, J. Y. and Joen, C. J. (2010) Types and density of calretinin-containing retinal ganglion cells in mouse. Neurosci. Res. 66; 141-150.

23. Lemke, G. and Reber, M. (2005) Retinotectal mapping: new insights from molecular genetics. Annu. Rev. Cell Dev. Biol. 21; 551-580.

24. Leventhal, A. G., Rodieck, R. W. and Dreher, B. (1985) Central projections of cat retinal ganglion cells. J. Comp. Neurol. 237; 216-226.

25. Levick, W. R., Oyster, C. W. and Takahashi, E. (1969) Rabbit lateral geniculate nucleus: sharpener of directional information. Science $165 ; 712-714$.

26. Levick, W. R. (1996) Receptive fields of cat retinal ganglion cells with special reference to the alpha cells. Progr. Ret. Eye Res. 15; 457-500.

27. Lugo, N. and Kicliter, E. (1988) Morphology of ganglion cells which project to the dorsal lateral geniculate and superior colliculus in the ground squirrel. Brain Res. 454; 67-77.

28. Masland, R. H. (2004) Neuronal cell types. Curr. Biol. 14; 497500 .

29. Masland, R. H. and Martin, P. R. (2007) The unsolved mystery of vision. Curr. Biol. 17; R578-582.

30. Pu, M., Berson, D. M. and Pan, T. (1994) Structure and function of retinal ganglion cells innervating the cat's geniculate wing: an in vitro study. J. Neurosci. 14; 4338-4358.

31. Rivera, N. and Lugo, N. (1998) Four retinal ganglion cell types that project to the superior colliculus in the thirteen-lined ground squirrel (Spermophilus tridecemlineatus). J. Comp. Neurol. 396; $105-120$.

32. Rockhill, R. L., Daly, F. J., MacNeil, M. A., Brown, S. P. and Masland, R. H. (2002) The diversity of ganglion cells in a mammalian retina. J. Neurosci. 22; 3831-3843.

33. Rodieck, R. W. (1998) The First Steps in Seeing, Sinauer Associates, Sunderland, MA.

34. Rowe, M. H. and Cox, J. F. (1993) Spatial receptive-field structure of cat retinal W cells. Vis. Neurosci. 10; 765-779.

35. Runyan, C. A., Schummers, J., Wart, A. V., Kuhlman, S. J. and 
Wilson, N. R. (2010) Response features of parvalbuminexpressing interneuron suggest precise roles for subtypes of inhibition in visual cortex. Neuron 67; 847-857.

36. Sanna, P. P., Keyser, K. T., Celio, M. R., Karten, H. J. and Bloom, F. E. (1993) Distribution of parvalbumin immunoreactivity in the vertebrate retina. Brain Res. 600; 141-150.

37. Shapley, R. and Perry, V. H. (1986) Cat and monkey retinal ganglion cells and their visual functional roles. Trends Neurosci. 9; 229-235.

38. Stein, J. J. and Berson, D. M. (1995) On the distribution of gamma cells in the cat retina. Vis. Neurosci. 12;687-700.

39. Sun, W., Li, N. and He, S. (2002) Large-scale morphological survey of mouse retinal ganglion cells. J. Comp. Neurol. 451; $115-126$

40. Sun, W., Deng, Q., Levick, W. R. and He, S. (2006) ON directionselective ganglion cells in the mouse retina. J. Physiol. 576; 197202.

41. Tailby, C., Solomon, S. G., Dhruv, N. T., Majaj, N. J., Sokol, S. H. and Lennie, P. (2007) A new code for contrast in the primate visual pathway. J. Neurosci. 27; 3904-3909.

42. Troy, J. B., Einstein, G., Schuurmans, R. P., Robson, J. G. and Enroth-Cugell, C. (1989) Responses to sinusoidal gratings of two types of very nonlinear retinal ganglion cells of cat. Vis. Neurosci. $3 ; 213-223$.

43. Vaney, D. I., Peichl, L., Wassle, H. and Illing, R. B. (1981) Almost all ganglion cells in the rabbit retina project to the superior colliculus. Brain Res. 212; 447-453.
44. Völgyi, B., Chheda, S. and Bloomfield, S. A. (2009) Tracer coupling patterns of the ganglion cell subtypes in the mouse retina. J. Comp. Neurol. 512; 664-687.

45. Waleszczyk, W. J., Wang, C., Benedek, G., Burke, W. and Dreher, B. (2004) Motion sensitivity in cat's superior colliculus: contribution of different visual processing channels to response properties of collicular neurons. Acta Neurobiol. Exp. 64; 209-228.

46. Wassle, H. and Boycott, B. B. (1991) Functional architecture of the mammalian retina. Physiol. Rev. 71; 447-480.

47. Weng, S., Sun, W. and He, S. (2005) Identification of ON-OFF direction-selective ganglion cells in the mouse retina. J. Physiol. 562; 915-923.

48. Yamada, E. S., Bordts, A. S. and Marshak, D. W. (2005) Widefield ganglion cells in macaque retinas. Vis. Neurosci. 22; 383393.

49. Yang, G. and Masland, R. H. (1994) Receptive fields and dendritic structure of directionally selective retinal ganglion cells. J. Neurosci. 14; 5267-5280.

50. Yonehara, K., Ishikane, H., Sakuta, H., Shintani, T., NakamuraYonehara, K., Kamiji, N. L., Usui, S. and Noda, M. (2009) Identification of retinal ganglion cells and their projections involved in central transmission of about upward and downward image motion. PLOS ONE 4; e4320.

This is an open access article distributed under the Creative Commons Attribution License, which permits unrestricted use, distribution, and reproduction in any medium, provided the original work is properly cited 